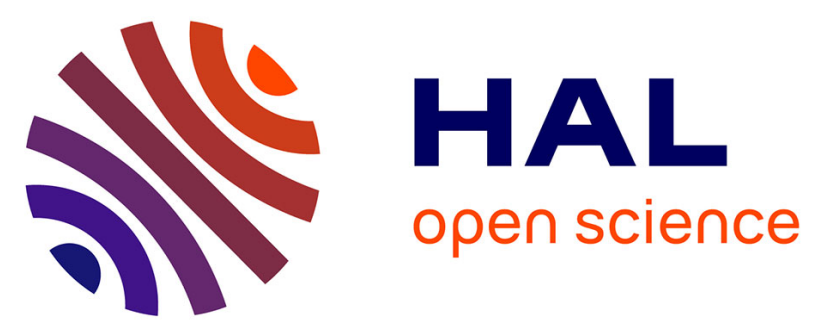

\title{
First report on Cretaceous vertebrates from the Algerian Kem Kem beds. A new procoelous salamander from the Cenomanian, with remarks on African Caudata
}

Tannina Alloul, Jean-Claude Rage, Rachid Hamdidouche, Nour-Eddine Jalil

\section{- To cite this version:}

Tannina Alloul, Jean-Claude Rage, Rachid Hamdidouche, Nour-Eddine Jalil. First report on Cretaceous vertebrates from the Algerian Kem Kem beds. A new procoelous salamander from the Cenomanian, with remarks on African Caudata. Cretaceous Research, 2018, 84, pp.384-388. 10.1016/j.cretres.2017.11.019 . hal-01675293

\section{HAL Id: hal-01675293 \\ https: / hal.sorbonne-universite.fr/hal-01675293}

Submitted on 4 Jan 2018

HAL is a multi-disciplinary open access archive for the deposit and dissemination of scientific research documents, whether they are published or not. The documents may come from teaching and research institutions in France or abroad, or from public or private research centers.
L'archive ouverte pluridisciplinaire HAL, est destinée au dépôt et à la diffusion de documents scientifiques de niveau recherche, publiés ou non, émanant des établissements d'enseignement et de recherche français ou étrangers, des laboratoires publics ou privés. 
First report on Cretaceous vertebrates from the Algerian Kem Kem beds. A new procoelous salamander from the Cenomanian, with remarks on African Caudata.

Tannina Alloul ${ }^{\mathrm{a}, *}$, Jean-Claude Rage $^{\mathrm{b}}$, Rachid Hamdidouche ${ }^{\mathrm{a}}$, Nour-Eddine Jalil ${ }^{\mathrm{b}, \mathrm{c}}$ (1)

${ }^{a}$ University of Sciences and Technology Houari-Boumèdiène, Laboratory of Geoynamic

Bassins and Orognesis, Algiers, Algeria

${ }^{\mathrm{b}}$ Sorbonne Universities, CR2P CNRS-MNHN-UPMC Paris 6, Department Origins and evolution, National Museum of Natural History, CP 38, 57 rue Cuvier, 75005 Paris, France ${ }^{c}$ Faculty of Sciences Semlalia, University Cadi Ayyad, Marrakesh, Morocco

*corresponding author: talloul@usthb.dz

E-mail addresses: talloul@usthb.dz (T. Alloul), jean-claude.rage@mnhn.fr (J.C. Rage), hamdidoucherachid@gmail.com (R. Hamdidouche), nour-eddine.jalil@mnhn.fr. (N.E. Jalil).

\section{Abstract}

In northwestern Africa, the Kem Kem plateau is a major source of continental Cenomanian fossils. The plateau extends across the Algerian-Moroccan border but, unlike the intensely worked Moroccan part, the Algerian side of the Kem Kem beds has received less attention. However, recent field work in Algeria resulted in the recovery of a locality that yielded a promising vertebrate assemblage. Among the fossils is a trunk vertebra belonging to a salamander, a group whose remains are extremely rare in Africa. The vertebra is procoelous and it presents combination of characters that suggest it belongs to a new taxon of unknown affinities. Although the putative new taxon is represented by a single specimen that is too poorly preserved to be formally named, the discovery is important for showing that salamanders were more diversified than expected in the Cretaceous of Africa. 
27 Keywords

28 Kem Kem

$29 \quad$ Algeria

30 Cenomanian

31 Amphibia

32 Caudata

33

\section{Introduction}

Caudata (i.e. salamanders) are primarily Laurasian amphibians (Bailon et al., 2011; Gardner and Rage, 2016). Most extant and extinct species occur in North America, Europe and Asia, which are the territories that made up the former Laurasia. These past and present ranges suggest that salamanders originated in Laurasia (Gardner and Rage, 2016). Outside of Laurasia, living salamanders occur only in the northern parts of three former Gondwanan continents (Frost, 2017): South America, the African Plate (Africa plus the Arabian Peninsula and Middle East) and India. The colonization of India does not appear problematic, because the Indian Plate has been in contact with Eurasia for a longer time (latest Cretaceous to early Eocene? Kapur and Khosla, 2016; Verma et al., 2016) than South America and Africa, both of which have been linked to Laurasia only recently, during the Neogene. The colonization of these two southern continents by modern salamanders appears to be a Neogene phenomenon. In Africa, fossils of both living and extinct taxa are known; they are rare but range from the Middle Jurassic to the Pleistocene (Gardner and Rage, 2016, and references therein). Here we describe the first salamander from the upper Cretaceous Kem Kem beds of Algeria. This specimen was collected from a locality known as Oued Bou Seroual. 


\section{African Caudata}

A few fossils document the recent history of African Caudata. The earliest known of these fossils comes from the early Pleistocene of Morocco and was referred to as Pleurodeles cf. waltl (Bailon et al., 2011). P. waltl is a living species of European affinities, which is consistent with the Laurasian (Eurasian) origin for living salamanders inhabiting northernmost Africa. The date of dispersal of living salamanders into Africa is unknown, the only certainty is to assume that it is older than the early Pleistocene.

Aside from Pleistocene fossils, patchy older remains document a history clearly distinct from the recent colonization. They all come from the northern part of Africa and range from the middle Jurassic (Bathonian; Haddoumi et al., 2016) to the early-middle Eocene (Gardner and Rage, 2016). The relationships of these fossils are either unknown or disputed. Of particular importance are the remains from the Cenomanian-Santonian interval (Late Cretaceous) assigned to the endemic genus Kababisha (Evans et al., 1996) or to a closely related form, cf. Kababisha (Rage and Dutheil, 2008; Gardner and Rage, 2016). Their presence in the Late Cretaceous of Africa was regarded either as the result of vicariance (Rage et al., 1993) or of a dispersal from Laurasia (Evans et al., 1996). Here, we report on a new specimen from the Cenomanian of Africa, which likely represents a salamander distinct from Kababisha.

\section{The Algerian Kem Kem and the fossiliferous locality}

The Kem Kem plateau of Algeria is located in the western part of the Saharan platform at the junction between the mountain chain of Ougarta and the Moroccan Anti-Atlas (Zellouf, 1987) (Fig. 1A). The name Kem Kem has a Berber origin meaning torn or shredded (Lavocat, 1954); the name Hammada is also used, which means a vast and rocky plateau. This plateau is almost tabular with a slight inclination to the north, it is semi-desertic and excavated by a very 
dense river network (Joly, 1962). It is $200 \mathrm{~km}$ long extending NE to SW from the village of Taouz in southeastern Morocco, to the village of Zegdou in southwestern Algeria (Joly, 1962) (Fig.1B). It is located approximately $1400 \mathrm{~km}$ southwest of Algiers and $350 \mathrm{~km}$ southwest of Bechar (Fig. 1A).

The wadis (i.e. rivers) that incise the surface of the Kem Kem as a dense network typically are not deep enough to expose the underlying marlstones and sandstones. In the Oued Bou Seroual area, however, the wadi Daoura does cut into the sandstone layer. A deposit rich in disarticulated micro-vertebrates was recovered recently in this region. It is situated in the central part of the Kem Kem plateau, $90 \mathrm{~km}$ northeast of Zegdou and $50 \mathrm{~km}$ east of the famous Gara Sbaa locality (Cenomanian, Morocco; Lavocat, 1948; Cavin et al., 2010) (Fig. 1B). The preliminary and unpublished list of vertebrates includes: Chondrichthyes (Onchopristis dunklei, O. numidus), Actinopterygii (Polypteriformes, Semionotiformes), Actinistia, Dipnoi, Amphibia (Anura), Squamata, Crocodylomorpha, Sauropoda, Theropoda, Pterosauria and, as reported here, a salamander.

\section{Geological setting}

The Cretaceous series of the Hammada, along the Algerian-Moroccan border was first and briefly described, on the Moroccan side, by Clariond (1933) during field work throughout the Hammada of Taouz. He described the following succession, from bottom to top: $120 \mathrm{~m}$ thick whitish and pinkish soft sandstone; $3 \mathrm{~m}$ thick calcareous sandstone with crystals of calcites and manganese spots, attributed to the Albian on the basis of the presence of the echinoderm Dorocidaris taouzensis; and a thick layer of limestones, which he divided into two parts, a lower part assigned to the Cenomanian, due to the presence of the ammonite Neolobites vibrayanus, and an upper part dated as Turonian on the basis of the presence of the gastropod Nerinea requieni. 
103 Kem beds into three formations: a lower continental formation commonly called 'Grès

104 infracénomanien' or 'Formation d'Ifezouane' assigned to the Albian (Choubert, 1948; Dubar,

105 1949; Ettachfini and Andreu, 2004); a second, lagoonal formation composed of colorful

106 marlstones with gypsum, assigned to the lower Cenomanian and called 'Marne versicolore à

107 gypse' (Choubert, 1948) or 'Formation d' Aoufous' (Dubar, 1949); and a third, marine

108 formation of Cenomanian-Turonian age, comprised of white marly-limestones including

109 flints, called 'Formation d'Akabou' (Dubar 1949).

111 Ifezouane and Aoufous formations into a single unit informally named the 'Kem Kem beds'.

112 The Kem Kem beds were assigned to the lower Cenomanian (Sereno et al., 1996; Cavin et al.,

113 2010) on the basis of close similarity between the vertebrate assemblage of these beds and

114 that of Bahariya, in Egypt (Catuneanu et al., 2006).

115 The Kem Kem beds in Oued Bou Seroual, Algeria, are reported here for the first time

116 and consist mainly of sandstone. The lower part includes thin reddish sandstones and

117 yellowish coarse sandstones, overlaid by reddish coarse sandstones; all these sandstones show

118 oblique and horizontal stratifications. The upper level comprises yellowish coarse sandstones

119 interspersed with greenish coarse friable sandstone; this is the richest level in terms of the

120 number of vertebrate fossils.

5. Material and methods

The poorly consolidated sandstones were screen washed using $1 \mathrm{~mm}, 800,500$ and

$124400 \mu \mathrm{m}$ mesh-size sieves. Three kilograms of matrix from the Oued Bou Seroual area were

125 processed. In spite of this small sample, the collected and treated sedimentary rocks delivered

126 diverse vertebrate assemblage, which includes about a hundred remains identifiable at high 
127 taxonomic level. The vertebrate micro-remains were subsequently sorted under

128 stereomicroscope (model Leica A60). The described specimen is housed in the

129 palaeontological collections of the Museum of the University of Sciences and Technology

130 Houari Boumediene (MUHB), Algeria.

132 6. Systematic Palaeontology

133 Lissamphibia Haeckel, 1866

134 Caudata Scopoli, 1777

135 Family indeterminate

136 Material: one trunk or anteriormost caudal vertebra (MUHB 1010001).

137

138 6.1. Description

MUHB 1010001 (Fig. 2A-J) is a small, slightly distorted vertebra (maximum length

140 from anterior rim of prezygapophysis to posterior rim of postzygapophysis $=2.1 \mathrm{~mm}$ ). Its

141 main characteristic is the procoelous nature of its centrum. In dorsal aspect, the vertebra is

142 elongate and narrow. The prezygapophyses are well developed, but their shape cannot be

143 determined precisely. The neural spine is very low. It appears as a ridge that runs along the

144 entire length of the neural arch; posteriorly, the ridge forms a low, triangular tubercle, but

145 anteriorly the ridge is so shallow that it is scarcely perceivable. The distal portions of the

146 transverse processes are broken off. Only their bases are preserved; those are broad and

147 positioned relatively posteriorly. In anterior view, the neural canal is large and the

148 prezygapophyses are approximately level with the top of the canal. The anterior cotyle is

149 filled by matrix. Short but strong anterior basapophyses are present on either side,

150 lateroventral to the cotyle. The bases of the transverse processes are directed lateroventrally.

151 They are not thick and they do not include a dorsal and a ventral elements; in other words, 
152 they are not true rib-bearers. In lateral view, the base of the transverse process is attached

153 obliquely (anterodorsally to posteroventrally) to the lateral wall of the neural arch. A low

154 ridge extends between the transverse process and the ventral part of the posterior condyle, but

155 there are no accessory ridges or flanges buttressing the process anteriorly. No vertebrarterial

156 foramen pierces the basis of the transverse process and the vertebra lacks spinal foramina. The

157 condyle clearly projects posteriorly; it appears as a bony continuation of the centrum and not

158 as a calcified infilling of a posterior cotyle. On the ventral face, a shallow but sharp keel

159 occupies the posterior two-thirds of the centrum length. There are no foramina on the ventral

160 surface. In posterior view, the condyle shows a large notochordal pit.

\subsection{Remarks}

MUHB 1010001 shows a combination of characters that is encountered only in

164 Caudata: presence of basapophyses; absence of buttresses on either side of the cotyle as a

165 result of the high position of the prezygapophyses; marked anterior orientation of the

166 prezygapophyses, which renders the interzygapophyseal constriction very shallow; presence

167 of a ridge extending between the transverse process and the condyle; and condyle non-

168 hemispheric, flat posteriorly, with a large notochordal pit. The vertebra lacks haemapophyses,

169 therefore it comes either from the trunk or the anteriormost caudal regions. In addition, the

170 absence of a double-processed rib-bearer (instead, seemingly replaced by a simple transverse

171 process) suggests that the vertebra belongs to an elongate, snake-like salamander. The

172 procoelous nature of the vertebra enables to narrow comparisons to procoelous salamanders,

173 which are inferred to be snake-like forms.

174 The vertebrae of Caudata are either amphicoelous or opisthocoelous, with a very few

175 exceptions that may be labelled procoelous. The nature of the posterior vertebral condyle,

176 which renders the vertebrae procoelous, has been disputed (Evans et al., 1996). Rage et al. 
177 (1993) regarded vertebrae with posterior condyles as really procoelous. However, according

178 to Evans et al. (1996), the posterior condyle is not a true condyle; instead, it is made up by the

179 infilling of the cotyle by calcified material and the vertebrae would be 'pseudoprocoelous'. It

180 is true that the posterior condyle is made by additional material in large vertebrae, but in small

181 vertebrae it appears to be a true, osseous condyle that is continuous with the centrum. The

182 nature of the posterior condyle of these salamanders remains to be really investigated, but this

183 issue is beyond the scope of our study.

Among Caudata, except some extant species of Ambystoma that are pseudoprocoelous

185 (Evans et al., 1996), a posterior condyle occurs only in some extinct Gondwanan taxa, which

186 are restricted to the Late Cretaceous. These fossils are Kababisha humarensis and $K$.

187 sudanensis fom the Cenomanian (or perhaps Campanian-Maastrichtian; Eisawi, 2015) of

188 Wadi Abu Hashim, Sudan (Evans et al., 1996), cf. Kababisha from the Cenomanian of

189 Morocco (Rage and Dutheil, 2008) and from the Coniacian-Santonian of Niger (Rage et al.,

190 1993; Gardner and Rage, 2016; JCR, work in progress), and Noterpeton bolivianum from the

191 Maastrichtian of Bolivia, South America (Rage et al., 1993).

192 The vertebra from the Algerian Kem Kem beds is readily distinguished from those of

193 other procoelous and/or pseudoprocoelous Caudata in being relatively more depressed and

194 less narrow (Fig. 2A-J vs 2K-M), in lacking vertebrarterial foramina and the anterior

195 accessory crests that buttress the transverse process, and in having strong anterior

196 basapophyses. It should be noted, incidentally, that the presence or absence of vertebrarterial

197 foramina was not addressed in the description of Noterpeton (Rage et al., 1993). Based on

198 well-preserved specimens, it may be stated here that such foramina are present in Noterpeton

199 as they are in other procoelous caudatans, except in the taxon from Oued Bou Seroual. The

200 Algerian vertebra further differs from those of K. humarensis and K. sudanensis in being

201 relatively more elongate (Fig. 2L, M). However, its elongation is somewhat reminiscent of a 
202

vertebra referred to a juvenile individual of Kababisha by Evans et al. (1996: text-fig. 9G-J).

Nevertheless, elongation of the specimen from Algeria is not related to a juvenile, age as demonstrated by its well-developed prezygapophyses and the moderate size of its neural canal.

In addition, the Algerian vertebra does not represent an intracolumnar variant in Kababisha or Noterpeton. In these two genera, all post-atlantal vertebrae are clearly taller and have anterior accessory crests or flanges. Consequently, we regard the salamander from Oued Bou Seroual as representing a new taxon, but defer naming it because currently only a single and incomplete vertebra is available.

\section{Discussion}

Assuming that Wadi Abu Hashim in Sudan is really Cenomanian in age as originally reported (Werner, 1994), and not Campanian-Maastrichtian as recently suggested (Eisawi, 2015), then the specimen from Oued Bou Seroual, cf. Kababisha from the Moroccan Kem Kem, and Kababisha humarensis and K. sudanensis from Sudan are the only salamanders known from the Cenomanian of Africa, and the only salamanders known from the CallovianTuronian of Gondwana, an interval of approximately 76 million years. These Cenomanian taxa represent the earliest known procoelous or pseudoprocoelous salamanders, an assemblage that extends up to the Maastrichtian. All known Cenomanian salamanders from Gondwana have procoelous (or pseudoprocoelous) vertebrae, whereas those from the Cenomanian of Laurasia have amphicoelous vertebrae (Gardner and DeMar, 2013; Skutschas, 2013).

Unfortunately, the new salamander does not help to resolve origin of the Gondwanan procoelous salamanders, i.e. either the result of vicariance or of a dispersal from Laurasia. This will remain unresolved until new palaeontologic discoveries. 
8. Conclusions

The Cretaceous Kem Kem beds, which extend through easternmost Morocco and westernmost Algeria, have produced numerous continental vertebrates of Cenomanian age in Morocco, but were not studied in Algeria. Recent field work on the Algerian side led to the recovery of a promising fossiliferous locality (Oued Bou Seroual). A small amount of

233 fossiliferous matrix produced a fairly diverse assemblage of vertebrates. Among them is a caudate amphibian, i.e. a salamander, represented by a procoelous vertebra. In Africa, salamanders are exceptionally rare, with only rare fossils known from the Middle JurassicHolocene and four living species. The salamander from Oued Bou Seroual cannot be identified within Caudata because it is represented by a single vertebra that is both incomplete and enigmatic. However, it may be stated that this salamander is distinct from the rare representatives of the group known from Africa.

\section{Acknowledgements}

242 The present study was conducted with the support of the Centre de Recherches sur la 243 Paléobiodiversité et les Paléoenvironnements (CR2P), UMR 7207 CNRS, Muséum National d'Histoire Naturelle, Paris, and the Laboratoire de Géodynamique des Bassins Sédimentaires et des Orogenèse (LGBSO), Algiers. Sylvie Crasquin enabled T. Alloul to study the fossil material in the CR2P. We thank Olga Otero (University of Poitiers), Gilles Cuny (University

247 of Lyon 1), Gaël Clément (Muséum National d'Histoire Naturelle, CR2P, Paris) and Didier 248 Dutheil (Paris) for their discussions, shared with T.A. that allowed the determination of 249 “fishes". Our thanks also go to Emmanuel Gheerbrant (Muséum National d'Histoire Naturelle, CR2P, Paris) for his help and thoughtful advices to T.A. We are grateful to Renaud Vacant for 251 his help for the preparation of fossil material and to Lilian Cazes who made the photographs 
252 (both from the CR2P). We thank J.D. Garner and an anonymous reviewer for their valuable

253 comments, which helped to improve the manuscript.

254 This work was supported by a grant from Franco-Algerian scholarship program (PROFASB+)

255 to TA, and by support of LBGSO to TA and RH. JCR and NEJ were funded by recurring 256 grants from the CNRS, the French Ministry of Research, and Sorbonne Universités to the 257 CR2P.

\section{References}

261

Bailon, S., Rage, J.C., Stoetzel, E., 2011. First fossil representative of the salamander crowngroup from a Gondwanan continent: Pleurodeles cf. waltl from the Quaternary of Morocco. Amphibia-Reptilia 32, 245-252.

Benyoucef, M., 2012. Le basin Crétacé du Guir (Sud-Ouest Algérien): Caractérisations lithobiostratigraphiques, sédimentologique and paléontologiques (Unpubl. PhD thesis). University of Tlemcen, $220 \mathrm{pp}$.

Catuneanu, O., Khalifa, M.A., Wanas, H.A., 2006. Sequence stratigraphy of the Lower Cenomanian Bahariya Formation, Bahariya Oasis, Western Desert. Egypt Sedimentary Geology 190, 121-137.

Cavin, L., Tong, H., Boudad, L., Meister, C., Piuz, A., Tabouelle, J., Aarab, M., Amiot, R., Buffetaut, E., Dyke, G., Hua, S., Le Loeuff, J., 2010. Verterbrate assemblages from the early Late Cretaceous of southeastern Morocco: An overview. Journal of African Earth Sciences 57, 391-412.

Choubert, G., 1948. Essai sur la paléogéographie du Mésocrétacé marocain. Volume Jubilaire 1920-1945, Société des Sciences Naturelles du Maroc, 307-329. 
Clariond, L., 1933. Les terrains primaires et la Hammada de Taouz (Confins algéro-marocains du Sud). Compte Rendu Sommaire des séances de la Société Géologique de France 2, $47-48$.

Dubar, G., 1949 Carte géologique provisoire du Haut Atlas de Midelt au 1/200 000 . Notice explicative. Notes et Mémoires du Service Géologique du Maroc 59 bis, 60 p.

Eisawi, A.A.M., 2015. Palynological evidence of a Campanian-Maastrichtian age of the Shendi Formation (Shendi Basin, central Sudan). American Journal of Earth Sciences 2, 206-210.

Ettachfini, E.M., Andreu, B., 2004. Le Cénomanien et le Turonien de la Plate-forme Préafricaine du Maroc. Cretaceous Research 25, 277-302.

Evans, S.E., Milner, A.R., Werner, C., 1996. Sirenid salamanders and a gymnophionan amphibian from the Cretaceous of the Sudan. Palaeontology 39, 77-95.

Frost, D.R. 2017. Amphibian species of the World: an online reference. Version 6.0 (accessed May 2017). Electronic database accessible at http://research.amnh.org/herpetology/amphibia/index.html. American Museum of Natural History, New York, USA.

Gardner, J.D., DeMar, D.G., 2013. Mesozoic and Palaeocene lissamphibian assemblages of North America: a comprehensive review. Palaeobiodiversity and Palaeoenvironments 93, $459-515$.

Gardner, J.D., Rage, J.C., 2016. The fossil record of lissamphibians from Africa, Madagascar, and the Arabian Plate. Palaeobiodiversity and Palaeoenvironments 96, 169-220.

Haeckel, E.,1866. Generelle Morphologie der Organismen. Vol. 2. Allgemeine Entwickelungsgeschichte der Organismen. Georg Reimer, Berlin, 462 pp.

Haddoumi, H., Allain, R., Meslouh, S., Metais, G., Monbaron, M., Pons, D., Rage, J.C., Vullo, R., Zouhri, S., Gheerbrant, E., 2016. Guelb el Ahmar (Bathonian, Anoual syncline, 
eastern Morocco): First continental flora and fauna including mammals from the Middle Jurassic of Africa. Gondwana Research 29, 290-319.

303

Joly, F., 1962. Etude sur le relief du Sud- Est Marocain. Travaux de l'Institut Scientifique Chérifien, série géologie et géographie physique 10, 578 p.

Kapur, V.V., Khosla, A., 2016. Late Cretaceous terrestrial biota from India with special reference to vertebrates and their implications for biogeographic connections. In: Khosla, A., Lucas, S.G. (Eds.), Cretaceous Period: Biotic Diversity and Biogeography. New Mexico Museum of Natural History and Science Bulletin 71, 161-172.

Lavocat, R., 1948. Découverte de Crétacé à vertébrés dans le soubassement de la Hammada du Guir (Sud marocain). Comptes Rendus de 1'Académie des Sciences 226, 1291-1292.

Lavocat, R., 1954. Reconnaissance géologique dans les Hammadas des Confins algéromarocains du sud. Service géologique du Maroc, Notes et Mémoires 116, 1-148.

Rage, J.C., Dutheil, D.B., 2008. Amhibians and squamates from the Cretaceous (Cenomanian) of Morocco. A preliminary study, with description of a new genus of pipid frog. Palaeontographica A 285, 6-22.

Rage, J.C., Marshall, L.G., Gayet, M., 1993. Enigmatic Caudata (Amphibia) from the upper Cretaceous of Gondwana. Geobios 26, 515-519.

Scopoli, I. A., 1777. Introductio at historiam naturalem, sistens genera lapidum, plantarum, edt animalium hactenus detecta, caracteribus essentialibus donata, in tribus divisa, subinde and legesnaturae. Gerle, Prague, 506 pp.

Sereno, P.C., Dutheil, D.B., Iarochene, M., Larsson, H.C.E., Lyon, G.H, Magwene, P.M, Sidor, C.A, Varricchio, D.J., Wilson, J.A., 1996. Predatory dinosaurs from the Sahara and Late Cretaceous faunal differentiation. Science 272, 986-991.

Skutschas, P.P., 2013. Mesozoic salamanders and albanerpetontids of Middle Asia, Kazakhstan, and Siberia. Palaeobiodiversity and Palaeoenvironments 93, 441-457. 
14

Verma, O., Khosla, A., Goin, F.J., Kaur, J., 2016. Historical biogeography of the late Cretaceous Vertebrates of India: Comparison of geophysical and paleontological data. In: Khosla, A., Lucas, S.G. (Eds.), Cretaceous Period: Biotic Diversity and Biogeography. New Mexico Museum of Natural History and Science Bulletin 71, 317-330.

Werner, C., 1994. Die kontinentale Wirbeltierfauna aus der unteren Oberkreide des Sudan (Wadi Milk Formation). Berliner Geowissenschaftliche Abhandlungen E 13, 221249.

Zellouf, K., 1987. Les nappes d'Alterites du secteur d'Oglat-Beraber: témoins de la dynamique qui a marqué le Sahara nord-occidental depuis le Précambrien (Unpubl. PhD thesis). University of Pau, $223 \mathrm{pp}$.

\section{Legend of figures}

Fig 1: A, geographical location of the Kem Kem plateau (grey area not mapped); modified from Benyoucef (2012). B, Satellite image of the area, with location of Oued Bou Seroual area, marked by a red dot. Image from Google Earth. [Print at 2-columns width]

\section{Fig. 2. Upper Cretaceous salamander post-atlantal vertebrae from Gondwana. A-J: Caudata} indet. from the Cenomanian of Oued Bou Seroual, Algeria, MUHB 1010001, trunk or anteriormost caudal vertebra, photographs (A-E) in anterior (A), left lateral (B), posterior (C), dorsal (D) and ventral (E) views and annotated drawings (F-J) in anterior (F), left lateral (G), posterior (H), dorsal (I) and ventral (J) views; (B, D, E, G, I, J with anterior to left). K: 
15

\section{ACCEPTED MANUSCRIPT}

351 al., 1993: fig. 2a; modified). L, M: Kababisha humarensis (Cenomanian or Campanian-

352 Maastrichtian?, Sudan), anterior trunk vertebra in anterior view (L) and posterior trunk

353 vertebra in right lateral view (M) (from Evans et al., 1996: figs 8a and 9c; modified).

354 Abbreviations: bp, basapophysis; cd, condyle; ct, cotyle; nc, neural canal; ns, neural spine; pr,

355 prezygapophysis; pt, postzygapophysis; tp, transverse process. Scale bars $=2 \mathrm{~mm}$.

356 [print at 1.5 column width]

357

358

359 


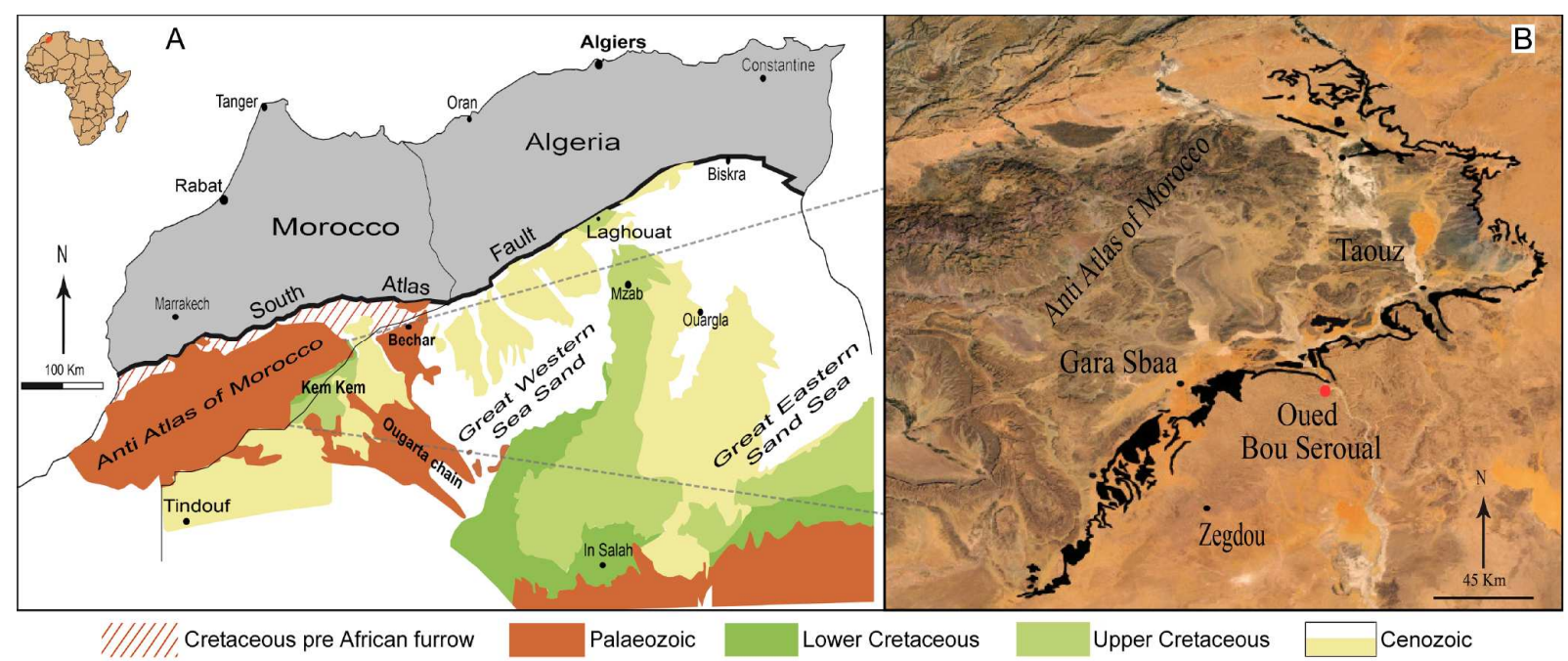



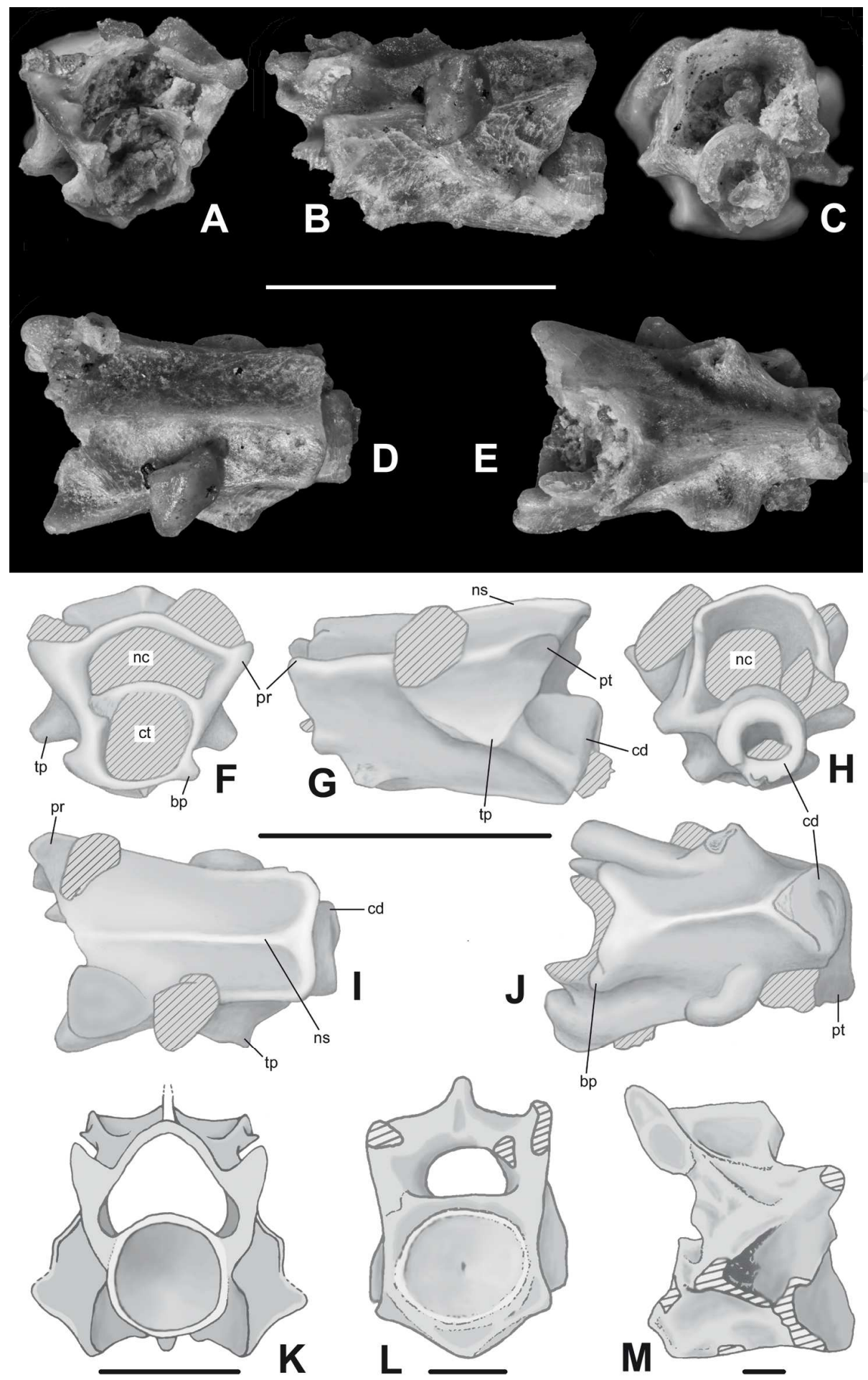
1 Highlight:

2

- The Cretaceous Kem-Kem area in northwestern Africa is a major palaeontological 3 site.

4

- The Moroccan Kem Kem where intensively worked but the Algerian side was

5 neglected.

6

- Recent finds in Algerian Kem Kem resulted in an exceptional Cenomanian fauna.

7 - The fauna includes a salamander, which is an exceptionally rare occurrence in Africa. 